JMD

26,3

200

Received September 2005

Revised December 2005

Accepted January 2006

\section{Workload factors impacting managers}

\author{
Robert F. Marsh and Shawn Blau
} College of Business, Sacred Heart University, Fairfield, Connecticut, USA

\begin{abstract}
Purpose - The paper seeks to identify elements of lean production that may be applicable to managers.

Design/methodology/approach - A survey was administered to 125 middle and lower level managers to assess perceptions about level of workload and amount of workload control. Principal components analysis was employed to identify primary factors.

Findings - Five primary factors accounted for 56 percent of total variance. The principal factors corresponded to the lean production concepts of work in process level, empowerment, and non value-added time.

Originality/value - These middle and lower level managers identified five primary factors that accounted for 56 percent of the variance in their self-reported levels of workload and control. Three of these factors correspond to existing metrics that have been utilized in lean production in industry.
\end{abstract}

Keywords Managers, Lean production, Labour efficiency

Paper type Research paper

\section{Introduction}

A typical manager's work day ... to beat the traffic, our typical manager starts for work early. Unfortunately, an accident on the way means our manager arrives with the crowd at the normal time. The plan for a proactive "jump" on the work to be done today goes out the window. Even though our manager checked e-mail until $11 \mathrm{pm}$ the night before, there is still new e-mail to be reviewed. After deleting the garbage and insignificant messages, this recent batch of e-mail creates more assignments for the new day.

Possibly because of the traffic, this day provides relief to the norm because our manager had time to actually dock her laptop and check e-mail before the first unscheduled guest arrives at the office door. Invariably, there are always some direct reports that consistently arrive early to work. Well past their e-mail check-up, these employees have begun their work day and are already to the point where managerial direction is required before they can proceed to complete tasks.

It would be a luxury for this manager if all daily interruptions came from expected sources, like direct reports and supervisors. But, just like those numerous e-mails, office visitors and phone callers seem to come from all directions, both within and outside the organization. A printout from the manager's planner shows five hours of scheduled meetings today and a business lunch. What is certain to be at least a ten-hour day is already more than half-consumed in dead time. Remaining time must be efficiently deployed just to stay on schedule for impending deliverables. Any thinking about the context of the work queue must be dealt with outside of that ten-hour day. Even with all the new gadgets the company has provided our manager, a
Journal of Management Development Vol. 26 No. 3,2007

pp. $200-212$

(C) Emerald Group Publishing Limited 0262-1711

DOI 10.1108/02621710710732119 
laptop, a personal digital assistant, and a Blackberry, our manager feels no more efficient or in control.

We paint this picture of a typical manager from hundreds of informal conversations with them. Those conversations were part of a more formal study of how managers allocate their time today and their perceptions about the level of workload and the level of control. Neither subject is new but studying the relationship between them given contemporary workplace shifts in technology and globalization merits attention. This research goes beyond a basic sampling of managers' work. The objectives are to tie in that quantifiable transaction data with perceptions about a manager's control of their assigned tasks. The authors hypothesize that relationships exist between perception of control and how time is spent. This research attempts to model those relationships for further testing.

\section{Background}

Our study of managerial activity, although observational, is ultimately aimed at improving managerial efficiency. Practical improvement methods cannot be prescribed without an understanding of how the resource (time) is being utilized. Oshagbemi's (1995) meta-analysis of manager time studies details 25 such studies between 1963 and 1990. Widely recognized from that list is Mintzberg's (1973) thesis. Although Mintzberg studied just five managers, all chief executive officers, the depth of information was so great that it serves as a foundation for all recent research. Mintzberg's work goes well beyond how managers spend their day (work characteristics) by defining ten various managerial roles. Contrary to prevailing thought at the time, Mintzberg found that a manager's day was quite fragmented into many transactions of short duration. The pace of work was quite hectic and left little time for planning.

Kurke and Aldrich (1983) confirm many of Mintzberg's findings, but like most published work in this field, they concentrate on senior leaders in relatively large organizations. Stewart's (1989) work includes lower and middle level managers in a similar exploration of managerial work but like the previous two papers, the objective of her research is centered on managerial roles. These significant contributions and the others cited by Oshagbemi (1995) provide data to check our results against but the aim of this research is at lower level managers. We are far more interested in how implementers spend their day, rather than planners of strategy. In our study, managerial roles or leadership traits are not characterized.

Another shortcoming of the aforementioned studies with respect to our objectives is the publication dates of the studies. The ubiquitous e-mail did not exist. The state of technology at the time of that research put constraints on communications that have been greatly eased. Today's manager, even at the lowest levels, is able to stay in contact with co-workers nearly around the clock, from almost any location. The new dynamics of e-mail and instant messaging certainly have changed the transactional load on managers. Not until just recently did a dedicated (always on) internet connection (broadband) become common in American households, a level that now reaches 30 percent (Belson, 2005). Although cell phone penetration impacted management responsibility well before broadband, the ability to coherently text message or answer e-mail via cell phone devices is just now gaining hold. The number of wireless devices with internet connections in use in the USA now measures 31 million (Frankel, 2005). Probably not coincidentally, the mention of work-related stress
Workload factors impacting managers

201 
JMD 26,3

202 in the popular press and the use of anti-depressant and anti-anxiety pharmaceuticals are at record highs (Hymowitz and Silverman, 2001).

Evidence of the recent changes comes from various sources. As long ago as 1998, a Pitney Bowes survey of over 1,000 US workers showed they received on average 190 messages each working day, broken down as telephone (52), e-mail (30), voice mail (22), interoffice mail (18), postal service (18), fax (15), post-it notes (11), phone message slips (10), pager (four), overnight courier (four), cellular phone (three), and postal express mail (three) (Internet Week, 1998). Just two years after those results, Pitney Bowes reported a US worker receives an average of 204 e-mails per day (Hymowitz and Silverman, 2001). The rate of e-mail growth is slowing but still significant. Just in the last two years the volume of incoming and outgoing e-mail per corporate user has doubled (Vara, 2004).

Another contemporary issue affecting many managers is globalization of supply chains (Chapman, 2001). It is not just buyer and supplier impacts, though. To fully utilize the clock, many companies develop new products and services in several parts of the world and pass on the work-in-progress to the next time zone, just like the shift change in a manufacturing plant. As firms build more international relationships, the work day often extends well beyond normal hours (Greene et al., 2003). Of course, as the number of relationships grows linearly, the number of communication contacts grows exponentially, and the sources for messages increases right along with that. Couple globalization with increased use of cross-functional teams within firms and it is evident the communication network for today's manager dwarfs what existed just ten years ago.

If we consider communication to be a fundamental management function, the complexity of management transactions must also be daunting in an historical context. Work assignments traditionally delivered from the top down in a hierarchical management structure now come from every direction. With the quality movement of the 1980s, managers were taught to be more facilitating to subordinates, therefore assignments could come from bottom-up. Along with enterprise resource planning in the 1990s came an emphasis on business processes that cut horizontally in organizations. That creates more work requests from outside the "department". Recognizing the financial benefits of supply chain management, firms must accept the burden of answering the call from many more partners than before. That not only means more bosses for the contemporary manager, but also greater difficulties in forecasting when and where the assignments come from.

The confluence of multiple information requests aided by sophisticated communication technologies sounds very much like the concept of "technostress". Brod (1984) coined the neologism "technostress" to denote worker and consumer distress caused by inadequately coping with new computer technologies. Weil and Rosen (1998; Rosen and Weil, 1999) detail the growing danger technostress poses as information and communication technologies have advanced in the last two decades. They point out that human psychology sets limits on the ability of workers to handle too much information at once. Miller (1956), in a famous early cognitive psychology experiment, found that most humans could only hold between five and nine "chunks" of information in their short-term memory at any one time. Consequently, workers tend to be less productive when they are forced to "multitask" excessively (Rosen and Weil, 1998). 
Managerial productivity tools

To cope with this nightmare of change, managers have been given both low-technology and high-technology tools. Low-tech solutions include basic time management and organization training techniques. The approach by Allen (2001) has gained some popularity, but age-old methods like to-do lists are still popular and effective (Fallows, 2005; Sandberg, 2004). For most managers, professional and personal workloads are co-mingled. Some firms try to alleviate certain aspects of the this burden by offering common services at the work facility, for example dry cleaning, day care, fitness clubs, and even medical services. Although more skill than tool, multitasking certainly makes more efficient use of time and is often facilitated by technology.

Certainly high-tech products have offered the most hope for managerial productivity improvement - at least that is the thought. The productivity paradox describes the lack of productivity gains given the significant investment in information technology in recent years (Franke, 1987). This research won't attempt to assess the validity of the productivity paradox, but the debate must be acknowledged.

Technologies for management and knowledge workers fall into two broad categories:

(1) communications; and

(2) data-related.

Limiting the discussion to recent communication advances, the list includes faster networks, wireless access, instant messaging, and web conferencing. For example, while a manager attends a required meeting, a wireless device may permit multitasking. Or, an instant message usually gets an instantaneous response and eliminates the queuing disposition that an e-mail would receive.

Data-related technologies include decision support or executive information systems, e-mail filters, advanced search tools, personal digital assistants, and voice recognition software. Of course, the overlap with communications is obvious and intentional. These tools allow the manager to quickly access information and make decisions. The direction of these technologies is toward actual knowledge management but the road is not well traveled yet.

\section{Lean production - an alternative approach}

Lean production is a manufacturing concept based on the "pull" system of repetitive processing. The term "lean" means less waste, therefore more efficient use of resources. Traditional production systems use a "push" system, in which large batches are processed at each step. Our overall hypothesis is that lower and middle managers in service industries still use the "push" system, and may benefit by using lean techniques. Lean techniques here do not mean lean staffing. We assume the managerial resource is capacity constrained. A predominant form of waste would likely be the time it takes to process work various workers, not the workers themselves.

The initial step is to identify which lean production metrics are applicable in the management environment of today's service industries. Metrics that have proven useful for measuring lean industrial production include work-in-process level (WIP), batch-size, cellular design, work standardization, work balancing, production leveling, total lead time, value creating time to total time, value creating steps to total steps,

\section{Workload factors impacting managers}

203 
JMD

26,3

204

inventory turns, empowerment, and setup time (Schonberger, 2001; Dailey, 2003; Georga, 2003; Henderson and Larco, 1999; Womack and Jones, 2003). For example, a lower WIP is associated with lean production and the lower the WIP, the leaner the production system. WIP is relatively easy to measure in manufacturing by simply counting the amount of work yet to be completed. For a manager, measuring WIP is much more difficult. Work to be completed queues in various areas including e-mail, phone mail, desk inboxes, regularly assigned tasks, and special assignments like projects. WIP is directly related to batch size, inventory turns, and total lead time from the above table.

Another related group is production leveling, cellular design, and work balancing. The ultimate objective is to achieve unitary flow (batch size of one) but principally to avoid production unevenness. A bottleneck is the slowest step in a sequential process and is readily identified by piles of inventory awaiting this resource. In administrative work, a bottleneck could equivalently be identified as the worker with the largest in-box, or to-do list. Even though the process may not be sequential, this worker is still restricting flow to other operations (workers) and creating unevenness.

Empowerment does not sound like a manufacturing doctrine, but is critically important to achieving leanness. Empowerment means giving workers greater control over the work process and respecting their opinions. Certainly this metric means the same thing in production and non-production environments, although the measurement of empowerment is not easily quantifiable.

\section{Research questions}

Our guiding hypothesis was that the workload of lower and middle-level managers in service industries could be alleviated by applying some of the techniques of lean management from industrial production. We administered a survey to determine what factors relevant to lean production could be reliably measured among lower and middle-level managers. We focused on the following questions:

- What is a reliable measurement of a lower and middle-manager's workload?

- Is it possible to measure how lower and middle-managers allocate their time at work?

- What is a reliable measurement of "work in progress" for lower and middle-managers?

- What is a reliable measurement of "lead time" for lower and middle-managers?

- What indicators of "lean production" can be reliably measured among lower and middle managers?

- Does reduced queue time increase individual productivity among lower and middle managers?

- Does reduced queue time increase group productivity among lower and middle managers?

This is an exploratory study and our primary goal is to identify which, if any, measures of lean production can be transferred usefully to lower and middle-management in service industries. 
We consider our subjects to be knowledge workers. Drucker (1959) first used the term "knowledge worker" to describe employees that work with intangible resources. More recently, Drucker (1988) has stated that "knowledge tends to be concentrated in service staffs, perched rather insecurely between top management and the operating people". Dove (1998) and Coates (1986) take an even broader view of what constitutes knowledge work but many prominent researchers agree that for knowledge work, "workers' brains comprise the means of production" (Ramirez and Nembhard, 2004). Based on these definitions, the authors strongly believe this sample to be representative of knowledge workers, but our assessment of workload is not concerned with how these subjects manage knowledge for future dissemination.

\section{Method}

Subjects were 125 lower and middle managers enrolled in part-time MBA classes at a Northeastern university. Participation was voluntary and responses kept anonymous, with no monetary or grade compensation. The surveys were handed out in class, with instructions to take them home and return them at the next class. Over 90 percent of surveys were returned and useable. Subjects were employed in lower and middle management at a wide range of organizations. The survey consisted of 42 items covering the subject's workload, daily tasks, projects, and attitudes. Sixteen items measured subjects' attitudes toward their workload and work control on a five-point Likert scale. The remaining 26 items covered the subjects' workload, daily tasks, and pending projects. Items queried the types of communications subjects received, the queue sizes in numbers of items and in time to complete, the time spent in various office activities, and the number and type of interruptions experienced throughout the day.

\section{Descriptive statistics}

In comparing our results to the previously reported data from 1998, e-mails per day were slightly higher while phone calls per day dropped significantly. The shift from phone to e-mail can be attributed to the greater acceptance and adoption of e-mail. Why the e-mail average is so much lower than the later Pitney Bowes survey could be attributed to spam filters, common today in corporate software packages. Our respondents reported a far smaller percentage of time spent in meetings, but much more time spent on the phone, than the higher level managers reported in Oshagbemi's (1995) meta-analysis. In fact, hours on the phone and answering e-mail amounted to over 40 percent of the typical day.

Almost one hour per day is spent "managing and prioritizing schedules and workloads, but not actually doing the work". In a manufacturing environment, this would be considered set-up time. A necessary hurdle for lean production is to reduce set-up time, as it wastes resources in a strictly productive sense. Strangely, that one hour is acceptable as the average Likert score to the question "I spend too much time prioritizing what to do" leaned heavily toward disagree (question 14). Interruptions averaged fewer than reported in other sources (Speier et al., 2003), but this item is very difficult to measure accurately without actual observation. The impact of interruptions on the flow of work was of great interest. On average, 43 percent of interruptions are dealt with on the spot, and quickly, and presumably with little effect to flow. Alternatively, 30 percent require an action item that would fall into a queue and

\author{
Workload factors \\ impacting \\ managers \\ 205
}


JMD

26,3

\section{6}

\section{Results}

To explore the relationship between measures of managers' workloads and measures of their attitudes, principal components analysis (SPSS, 2002) was performed using Varimax rotation (Kaiser, 1958; Norusis, 2004) to identify primary factors. Cattell's (1978) scree plot was used to select the number of primary factors to rotate. Five primary factors were identified which accounted for over 56 percent of total variance (Figure 1). The rotated factor matrix is shown in Table I.

\section{Description of the five factors}

For the first factor, the following items loaded highest:

(1) If all interruptions stopped, approximately how long would it take in hours to finish the projects in progress? Loading: +0.978 .

(2) How many projects are you working on? Please consider a project to be a job with multiple related activities required for competition. Loading: +0.974

(3) If all interruptions stopped, approximately how long would it take in hours to get through the items on your desk/floor/cabinets? Loading: +0.970 .

(4) About how many employees at your work site? Loading: +0.960.

Figure 1.

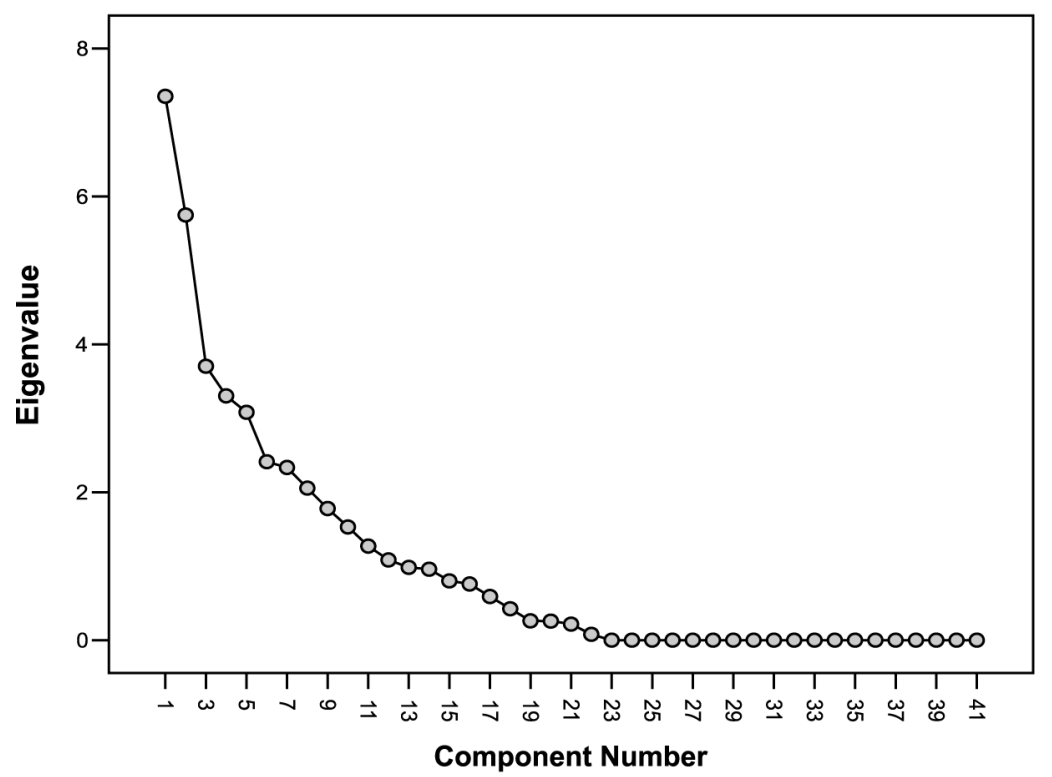




\begin{tabular}{|c|c|c|c|c|c|}
\hline & 1 & 2 & $\begin{array}{c}\text { Component } \\
3\end{array}$ & 4 & 5 \\
\hline projectq & 0.978 & 0.019 & -0.012 & 0.012 & 0.109 \\
\hline projects & 0.974 & 0.006 & -0.016 & 0.060 & 0.059 \\
\hline inboxq & 0.970 & 0.018 & -0.079 & 0.010 & -0.063 \\
\hline siteee & 0.960 & 0.055 & 0.119 & 0.039 & 0.084 \\
\hline writtentodo & 0.848 & 0.067 & 0.002 & 0.116 & -0.107 \\
\hline emailq & 0.600 & 0.089 & -0.058 & -0.347 & -0.285 \\
\hline q16 & -0.490 & -0.075 & 0.060 & -0.195 & 0.336 \\
\hline q6 & -0.275 & 0.847 & 0.017 & -0.226 & -0.151 \\
\hline q13 & 0.157 & -0.818 & 0.042 & 0.296 & 0.119 \\
\hline spotpct & -0.142 & -0.760 & 0.145 & -0.145 & -0.193 \\
\hline $\mathrm{q} 4$ & -0.224 & -0.727 & -0.161 & 0.064 & 0.112 \\
\hline q11 & -0.217 & -0.678 & -0.093 & 0.116 & -0.177 \\
\hline q14 & -0.294 & 0.675 & 0.213 & 0.324 & -0.325 \\
\hline q8 & -0.339 & -0.621 & -0.060 & -0.317 & -0.135 \\
\hline orghrs & 0.253 & 0.567 & -0.205 & 0.355 & -0.054 \\
\hline q5 & 0.403 & 0.457 & 0.101 & -0.092 & 0.069 \\
\hline tododesk & 0.155 & -0.423 & -0.239 & -0.084 & -0.412 \\
\hline todo & -0.142 & 0.381 & 0.187 & 0.287 & -0.285 \\
\hline q9 & -0.222 & 0.077 & 0.706 & 0.080 & -0.347 \\
\hline phonein & 0.013 & -0.214 & 0.613 & 0.010 & -0.351 \\
\hline phoneq & 0.370 & -0.135 & 0.605 & 0.066 & 0.101 \\
\hline meethrs & 0.135 & 0.459 & 0.579 & -0.191 & 0.027 \\
\hline phoneday & -0.073 & 0.046 & 0.575 & 0.177 & 0.168 \\
\hline reports & -0.009 & 0.264 & 0.565 & -0.072 & 0.151 \\
\hline q10 & -0.158 & 0.356 & 0.411 & -0.094 & -0.005 \\
\hline q12 & 0.358 & 0.312 & 0.362 & -0.211 & -0.218 \\
\hline q15 & -0.263 & -0.305 & 0.329 & 0.195 & 0.315 \\
\hline emergency & 0.150 & 0.487 & -0.074 & 0.676 & -0.173 \\
\hline emailhrs & -0.114 & -0.222 & -0.181 & 0.638 & 0.049 \\
\hline q2 & 0.176 & 0.008 & 0.486 & 0.631 & 0.143 \\
\hline emailsin & -0.019 & -0.032 & -0.041 & -0.487 & -0.078 \\
\hline emailsday & -0.120 & 0.256 & -0.409 & 0.462 & 0.019 \\
\hline todopct & 0.042 & 0.230 & 0.028 & -0.450 & 0.439 \\
\hline level & -0.391 & -0.024 & -0.266 & -0.417 & -0.196 \\
\hline otherinterrup & -0.085 & 0.243 & -0.220 & -0.381 & 0.043 \\
\hline q3 & -0.313 & 0.000 & 0.182 & -0.237 & 0.642 \\
\hline interruptday & -0.081 & -0.062 & -0.031 & 0.002 & 0.616 \\
\hline $\mathrm{q} 1$ & 0.169 & 0.327 & 0.330 & 0.170 & 0.607 \\
\hline phonehrs & 0.159 & 0.051 & -0.064 & 0.240 & 0.564 \\
\hline q7 & 0.138 & -0.349 & -0.229 & 0.330 & 0.533 \\
\hline employees & 0.104 & 0.229 & 0.087 & 0.035 & -0.301 \\
\hline
\end{tabular}

Notes: Extraction method: principal component analysis; rotation method: Varimax with Kaiser normalization; rotation converged in ten iterations
Workload factors impacting managers

207

Table I.

Rotated component matrix

(5) Approximately how many items are currently in your written to-do list, recorded on your PDA, or recorded on some other software? Loading: +0.848 .

(6) If all interruptions stopped, approximately how long would it take in hours to catch up on old e-mails? Loading: +0.600 . 
JMD

26,3

208
We have used 0.6 as a minimal absolute value loading. With the exception of the fourth item on this list, all have to do with the level of perceived workload. As discussed before, the amount of work-in-process is a common metric of lean production, and an equivalent in managerial operations could be the work queued up in in-boxes, scheduled and regular assignments (including projects), and other informal systems. We label this factor "WIP" and consider it a simple tool to inversely measure leanness.

The fourth item merits further discussion. The survey inquired about number of employees in the organization and at the site. Only the site item correlated with this factor. The inference could be made that number of employees at a given site correlates with WIP and therefore leanness. Similar to the exponential relationship between the number of communication channels and the number of people in a workgroup, the WIP could also be related to the number of employees at a work site. This indicates an inverse relationship between the size of the work site (although not of the organization itself), and the "leanness" of WIP. This result confirms popular discussions of the efficiency of skunkworks and smaller work units (Adams and Brock, 1986; Peters, 1987; Peters and Austin, 1986). It also agrees with the empirical results of Carillo and Kopelman (1991), demonstrating a similar relationship in the financial services industry. They found that the smallest branches of a financial services company were approximately 31 percent more efficient than the largest branches, and that the branches with the least vertical complexity were about 44 percent more productive than the branches with the most hierarchical complexity.

The following items loaded most highly on the second factor:

(1) "I feel highly stressed when I have too much to do". Loading: +0.847.

(2) "I can manage the number of my work assignments effectively". Loading: -0.818 .

(3) What percentage of your daily interruptions are completely settled on the spot quickly? Loading: -0.760 .

(4) "I feel more effective when I have a lot of work to do". Loading: -0.727.

(5) "Interruptions do not hinder my completing assignments". Loading: -0.678.

(6) "I spend too much time prioritizing what to do". Loading: +0.675 .

(7) "I have sufficient uninterrupted time to concentrate on work". Loading: -0.621.

These items clearly have in common a perceived level of control, or lack thereof, as answered. Empowering workers is a requirement of lean systems (Schonberger, 2001). Empowered workers have been delegated a higher level of responsibility and have demonstrated a higher sense of control (Schonberger, 2001). We label this factor "empowerment" and as with the first factor, positively loaded items are considered less lean.

The highest loading items for the third factor include:

(1) "I do not answer phones or look at e-mail while dedicating efforts toward a particular assignment”. Loading: +0.706 .

(2) Approximately how many items are currently in your phone messages unanswered but archived (all work phone numbers)? Loading: +0.613 . 
(3) If all interruptions stopped, approximately how long would it take in hours to clean up archived phone messages? Loading: +0.605 .

An obvious commonality is the phone reference, but many daily phone calls also give the appearance of a manager plagued by hindrances to accomplishing tasks. For this reason, we label this factor "non-value time". Of course, lean manufacturing systems emphasize the maximization of value-adding time by eliminating unnecessary activities and movement (Schonberger, 2001). Too many phone calls would be an interruption to flow. Hours each day in meetings is like machine downtime. Workers feel one-third of meeting time is unproductive (Elsayed-Elkhouly et al., 1997). These are in opposition to the desired lean state, so like the two factors above, positively loaded items are considered less lean.

Factor 4:

(1) What percentage of your daily interruptions must be dealt with immediately and require all other work stopped? Loading. +0.676 .

(2) On an average day, how much time in hours is spent answering e-mails? Loading: +0.638 .

(3) "My assignments come from my direct manager(s)". Loading: +0.631.

(4) Approximately how many items are currently in your e-mail in-box whether opened or not? Loading: -0.637 .

All of the highly loading items for this factor indicate subordinate employees, who spend most of their time following direct orders, and have little freedom to formulate their own tactics. Therefore, we have labeled this factor "facilitation".

Factor 5:

(1) "I can choose not to accept assignments based on my current workload". Loading: +0.642 .

(2) Approximately how many office interruptions do you receive each day? Loading: +0.616 .

(3) "I have control over the work directed to my subordinates". Loading: +0.617.

At the present time, we have to little data to delineate this factor, or to formulate any hypothesis about its relation to lean metrics. Therefore, we must leave it indeterminate pending further research.

\section{Conclusion}

In this exploratory analysis of the perceptions and attitudes of middle-managers regarding their workloads, we have identified five primary factors that together account for approximately 56 percent of total variance. Based on face validity, the first four of these factors, labeled "WIP", "empowerment", "non-value time", "facilitation", appear to correspond to commonly accepted lean production constructs. Validation of these factors and elucidation of the relationships between them awaits further research. Four of the five primary factors demonstrate content validity, since the questions relate to the construct (Kline, 1994; Spector, 1992). They also demonstrate face validity since the relationship between the items and the construct is not hidden (Kline, 1994; Spector, 1992). However, much more research is required to demonstrate construct validity
Workload factors impacting managers

209 
JMD

26,3

210
(Cronbach and Meehl, 1955; Kline, 1994), to prove empirically that the factors actually measure the characteristics we hypothesize. In testing for that construct validity, we hope to also create a valid measure of leanness for knowledge-based work.

\section{References}

Adams, W. and Brock, J.W. (1986), The Bigness Complex, Pantheon, New York, NY.

Allen, D. (2001), Getting Things Done: The Art of Stress-Free Productivity, Viking Penguin, New York, NY.

Belson, K. (2005), “Cable's new pitch: reach out and touch someone”, New York Times, May.

Brod, C. (1984), Technostress: The Human Cost of the Computer Revolution, Addison-Wesley, Reading, MA.

Carillo, P.M. and Kopelman, R.E. (1991), "Organization structure and productivity: effects of subunit size, vertical complexity, and administrative intensity on operating efficiency", Group and Organization Studies, Vol. 16 No. 1, pp. 44-59.

Cattell, R.B. (1978), The Scientific Use of Factor Analysis, Plenum, New York, NY.

Chapman, J.A. (2001), "The work of managers in new organisational contexts", The Journal of Management Development, Vol. 20 No. 1, pp. 55-68.

Coates, J. (1986), “Three models for white collar productivity improvement", Industrial Management, Vol. 28 No. 2, pp. 7-14.

Cronbach, L.J. and Meehl, P.E. (1955), "Construct validity in psychological tests", Psychological Bulletin, Vol. 52, pp. 281-302.

Dailey, K.W. (2003), The Lean Manufacturing Pocket Handbook, D.W. Publishing, Grand Blanc, MI.

Dove, R. (1998), "The knowledge worker", Automotive Manufacturing \& Production, Vol. 110 No. 6, pp. 26-8.

Drucker, P. (1959), The Landmarks of Tomorrow, Harper \& Row, New York, NY.

Drucker, P. (1988), "The coming of the new organization”, Harvard Business Review, Vol. 66 No. 1, pp. 3-11.

Elsayed-Elkhouly, S.M., Lazarus, H. and Forsythe, V. (1997), "Why is a third of your time wasted in meetings?", Journal of Management Development, Vol. 16 No. 9, pp. 672-6.

Fallows, J. (2005), “To-do list: shop, pay bills, organize brain”, New York Times, March 20.

Franke, R.H. (1987), "Technological revolution and productive decline: computer introduction in the financial industry", Technological Forecasting and Social Change, Vol. 31, pp. 143-54.

Frankel, A. (2005), “The willing partner”, Technology Review, July 1, pp. 36-8.

Georga, M.L. (2003), Lean Six Sigma for Service, McGraw-Hill, New York, NY.

Greene, J., Carey, J., Arndt, M. and Port, O. (2003), "Reinventing corporate R\&D: now even companies with big research budgets don't try to invent everything in-house”, Business Week, September 22, pp. 74-6.

Hymowitz, C. and Silverman, R.E. (2001), "Stressed out: can workplace stress get worse? - In soft economy, workplace stress may get worse - in this economy - you bet; add financial uncertainty to general job overload", Wall Street Journal, January 16.

Henderson, B. and Larco, J.L. (1999), Lean Transformation: How to Change Your Business into a Lean Enterprise, Oaklea Press, Richmond, VA.

Internet Week (1998), "Message madness", Internet Week, June 29, p. 43. 
Kaiser, H.F. (1958), "The Varimax criterion for analytic rotation in factor analysis", Workload factors Psychometrika, Vol. 23, pp. 187-200.

Kline, P. (1994), An Easy Guide to Factor Analysis, Routledge, New York, NY.

Kurke, L.B. and Aldrich, H.E. (1983), "Mintzberg was right! A replication and extension of the nature of managerial work, management", Science, Vol. 29 No. 8, pp. 975-84.

Miller, G. (1956), "The magical number seven, plus or minus two: some limits on our capacity for processing information", Psychological Review, Vol. 63, pp. 81-97.

Mintzberg, H. (1973), The Nature of Managerial Work, Harper \& Row, New York, NY.

Norusis, M. (2004), SPSS 12.0 Guide to Data Analysis, Prentice-Hall, Englewood Cliffs, NJ.

Oshagbemi, T. (1995), "Management development and managers' use of their time", The Journal of Management Development, Vol. 14 No. 8, p. 19.

Peters, T. (1987), Thriving on Chaos, Knopf, New York, NY.

Peters, T. and Austin, N. (1986), A Passion for Excellence, Warner, New York, NY.

Ramirez, Y. and Nembhard, D. (2004), "Measuring knowledge worker productivity, a taxonomy", Journal of Intellectual Capital, Vol. 5 No. 4, pp. 602-28.

Rosen, L.D. and Weil, M.M. (1998), "Multitasking madness”, Context Magazine, pp. 70-2.

Rosen, L.D. and Weil, M.M. (1999), "TechnoProfessionals: rules for thriving in the new millenium", HDSAware! (online magazine of Hitachi Data Systems).

Sandberg, J. (2004), "To-do lists can take more time than doing, but that isn't the point", Wall Street Journal, September 8 (Eastern edition).

Schonberger, R.J. (2001), Let's Fix It: Overcoming the Crisis in Manufacturing, The Free Press, New York, NY.

Spector, P.E. (1992), Summated Rating Scale Construction: An Introduction, Sage Publications, Thousand Oaks, CA.

Speier, C., Vessey, I. and Valacich, J.S. (2003), "The effects of interruptions, task complexity, and information presentation on computer-supported decision-making performance", Decision Sciences, Vol. 34 No. 4, pp. 771-97.

SPSS (2002), SPSS 12.0 for Windows, SPSS, Chicago, IL.

Stewart, R. (1989), "Studies of managerial jobs and behavior: the ways forward", The Journal of Management Studies, Vol. 26 No. 1, pp. 1-10.

Vara, V. (2004), "Consumer technology; taming the e-mail monster: how companies are trying to get a handle on way too much mail", Wall Street Journal, December 13 (Eastern edition).

Weil, M.M. and Rosen, L.D. (1998), Technostress: Coping with Technology@Work@Home @ Play, Wiley, New York, NY.

Womack, J.P. and Jones, D.T. (2003), Lean Thinking: Banish Waste and Create Wealth for Your Corporation, revised edition, The Free Press, New York, NY.

\footnotetext{
About the authors

Robert F. Marsh, Assistant Professor of Management, received his $\mathrm{PhD}$ in Operations Management from the University of Cincinnati. Bob has over a decade of industry and consulting experience in operations. He has published in several leading operations management research journals, including Journal of Operations Management, IIE Transactions on Scheduling and Logistics, International Journal of Operations \& Production Management, and International Journal of Production Research. Robert F. Marsh is the corresponding author and can be contacted at: marshr@sacredheart.edu
} 
$\mathrm{JMD}$

26,3

212
Shawn Blau, Assistant Professor of Management, received a BA from the University of the State of New York, an MA from Norwich University, and a $\mathrm{PhD}$ from Union Institute and University. His research includes entrepreneurship, lean scheduling, organizational behavior, and business ethics. Professor Blau has been teaching at Sacred Heart University since 2001, after a career in the advertising industry. His teaching includes organizational management, organizational behavior, human resource management, and entrepreneurship - where he serves as mentor for undergraduate and MBA student business plan competitions. Professor Blau has presented research at various academic conferences, and was managing editor of the New England Journal of Entrepreneurship.

To purchase reprints of this article please e-mail: reprints@emeraldinsight.com Or visit our web site for further details: www.emeraldinsight.com/reprints 